\title{
ASEAN COMISSION ON PROMOTION AND PROTECTION OF RIGHTS OF WOMEN AND CHILDREN ( ACWC) POLICIES IN ME VIOLENCE RESPONSE TO WOMEN IN THE SPIRIT
}

\author{
Rini Afriantari ${ }^{1}$, M. Budiana ${ }^{2}$ \\ ${ }^{1,2}$ Dean and Senior Lecturer at Universitas Pasundan \\ Faculty of Social and Political Sciences \\ Department of International Relations \\ ${ }^{1}$ Riniafriantari4@gmail.com
}

\begin{abstract}
The conflict in Rohingya is not a new thing for countries in the Southeast Asia region, this conflict has been going on for a long time and is one form of gross human rights violations. Many of the Rohingya people who accept physical and psychological violence are no exception for women, women in the Rohingya not only accept ordinary physical violence but also accept sexual violence as well. This particular issue of Rohingya as a broader term could be stressed in three areas such as the violation of international humanitarian law, the demarcation and dispute of region issue and the social conflict issue and also abusing of power from Myanmar authority's forces. However, in this particular issue, researchers' current studies are aims to explain why ACWC (ASEAN Commission on Promotion and Protection of Women and Children) seems helpless in dealing with violence against women that occurs in the Rohingya. Therefore, in this research we would like to give the different perspective by analyzing the ACWC limitation because of sovereignty issue concurred on Myanmar. Nevertheless, this paper will be providing the theoretical approach in order to understand deeper on the issue. This paper also explains why ACWC have difficulties to execute their programs towards protection of right of women and children. In addition, this paper based on qualitative methods by analyzing towards literature such as international articles and journals.
\end{abstract}

\section{Keywords : Human Rights, Rohingya, ACWC, Non-Intervention}

\section{Introduction}

In a book called Rohingya Belong To Arakan And Then Burma And So Do Participate by Abu Tahay who is the chairman of the Rohingya Ethnic group explains, that the Rohingya Ethnics originally came from ancient people who had Indo-Aryan ancestry which is a a group of Indo-European families living in the Rakhine or Arakan region of Myanmar[1]. Conflicts in the Rohingya have been recorded since a long time ago around 1900. The Burmese country, formerly known as Burma, was independent from Britain on January 4, 1948. If drawn early the conflict in Rohingya began since the post World War II. The Rohingya and Rakhine ethnic who both lived in Arakan had started to conflict because at that time the Rohingya favored the British while the Rakhine favored the Japanese, this made the Rohingya cornered by Rakhine because the Rohingya were ethnic minorities. The conflict worsened when the Myanmar government issued the 1982 Burma Citizenship Law where Rohingya was not recognized as a Myanmar citizen in the government's decision.

This longstanding conflict has caused many losses to the Rohingya such as the loss of shelter, physical and mental damage. The violence does not stop there, it is known that many Rohingya women get physical violence, especially sexual violence from Myanmar security forces. Women were subjected to sexual violence allegedly because they were seen as guardians and spreaders of ethnic 
identity that represented the future of the community. If we refer to the Universal Declaration of Human Rights (UDHR) it is clear that the Myanmar government has violated Human Rights because it has committed several violations such as: a) The right to be free to move and move, b) The right to be free from torture and violence, c) Right to education, d) Right to try and trade, e) Right to freedom of belief and worship .

The conflict in Rohingya especially the case of violence against women is certainly one thing that should receive more attention from ASEAN because this case has entered into gross human rights violations. ASEAN itself has issued a Joint Communique (Joint Communiqué) who expressed their collective views on human rights and their commitment to respect it as it existed in the Vienna Declaration. As a form of implementation of this joint communique ASEAn established several integral special human rights organizations, one of which was the ACWC (ASEAN Commission on the Promotion and Protection of the Rights of Women and Children) which specifically handles cases of human rights against women and children. So the ACWC as a body under ASEAN that takes care of women's human rights issues should have taken further action in Rohingya, in accordance with the ACWC work program contained in the ASEAN Regional Plan of Actions on Elimination of Violence Against Women. But in reality the ACWC did not make a real movementin handling cases of violence against women in Rohingya, then what factors caused the powerlessness of ACWC in dealing with violence against women in Rohingya?.

The theory of constructivism was born after World War II to criticize mainstream theories such as, neorealism and neoliberalism. This theory was first introduced by Nicholas Onuf in the 1980s. The theory of constructivism has two foundations, the first is the belief that the structures that hold humanity together are more determined by shared ideas than material forces. In other words, theoreticians of Constructivism believes that the social world is not something given, the social world is not something in " the outside there" that laws can be found through scientific research and explained by scientific theories, such as that proposed the Behavioralisme and Positivism. But the social world is an intersubjective area. According to Alexander Wend (1992) the social structure of the theory of constructivism has three components namely,

1) Shared knowledge

Shared knowledge is a dimension of knowledge that has been constructed by interactions between international relations actors. This component is very dynamic and intersubjective, this shared knowledge is the reference for taking action for the actors. In line with this argument Jennifer Sterling Folker writes " constructivism shows that even our most enduring institutions are based on collective understanding ".

2) Material resources

Material resources are empirical facts independent of shared knowledge. Cases of terror in the WTC, earthquake disasters, the Indonesian Embassy in Japan, civil servants and others are considered as meaningless material.

3) Practice

Practice is the behavior of international relations actors which are variables that are influenced by the construction of knowledge that they build collectively and are dynamic.

Constructivism is more free and respectable because it can reject or accept the international system, reshape the model of mutually beneficial relations, or that is desirable based on regulations, structuration and verstehen in speech acts.

\subsection{International Organization}

Organisasi International is an organization created by members of the international community voluntarily or based on a common desire to achieve a goal to bring peace and purpose in the system of international relations 
concerning the interests of various countries.As for some of the conditions of an organization referred to as an international organization are as follows.

1) The goal must be an international destination.

2) Must have members, where each member has voting rights.

3) Established based on the articles of association and must have headquarters ( headquarters ) for the survival of the organization.

4) Officials / employees who have the task of carrying out the work of the organization must consist of various nationalities / countries.

5) Organizations must be funded by members from various countries / nations. Organizations must be independent (independent) and must still be active. Organizations that have been inactive for more than five years are no longer recognized.

The classification of international organizations based on objectives according to the United Nations can be divided into,

1) An organization with a general purpose, for example, is the United Nations.

2) Organizations with specific goals are organizations such as the IAEA (International Atomic Energy Agency) and WHO (World Health Organization.

The classification of organizations by type of membership can be divided into,

1) State or Non state.

2) Regional or Universal.

An organization must be established with the objectives and activities that have been planned, because with planned goals and activities, an organization can run in a directed manner. The function of international organizations is influenced by the role of international organizations, the functions of international organizations can be described in general terms, as follows:

1) Articulation and aggregation

2) Norm

3) Recruitment
4) Socialization

5) Making Regulations

6) Application of Regulations

7) Adjudiction Rule

8) Information

9) Operation

The role of international organizations according to Clive Archer (1983: 136-137) is as follows (T. May Rudy, 2005: 29):

Instrument (tool / means), that is to reach agreement, suppress conflict intensity (if any) and harmonize actions.

1) Arena (forum / forum), which is to gather consultations and initiate joint decision making or the formulation of international agreements ( convention, treaty, protocol, agreeme nt and so forth).

2) Actors (actors), that international organizations can also be autonomous actors and act in their own capacity as an international organization and not just the implementation of the interests of their members

\subsection{Non-Traditional Security Theory}

The non-traditional security study emerged after the end of the cold war between the United States and the Soviet Union. According to Terry Terriff, et al . Non-traditional security has four general characteristics. First, most of these problems are not state-centered but rather based on non-state factors or actors. Second, security threats do not have a certain geographical area. Third, the threat cannot be resolved solely by relying on traditional security policies. Fourth, the targets of threats are individuals and countries (Terriff, et al, 1999: 115-116)."Threats" ( threats ) that form the basis of security are no longer focused solely on weapons or military security issues. "The threat" can mean disease, human trafficking, narcotics, trafficking senjat a, poverty, illiteracy, infectious virus, or the like that is felt by the citizens, not the state itself.

\subsection{Human Rights Theory}

Theoretical understanding of human rights is: "rights inherent in human dignity 
attached to it as a creature of God Almighty, or basic rights that are the principle as a gift of God. It means that human rights are rights owned by humans according to their nature which cannot be separated from their essence, therefore human rights are noble and sacred. Provisions on human rights have been regulated in the Universal Declaration of Human Rights in 1948, this declaration had consequences for UN member states to state that they recognized the rights of everyone as human rights that must be respected. Based on this declaration of the UN member states declared their obligation to respect (to respect), shield (to protect), and meet (to fullfil) rights every citizen.

Human rights can be differentiated into :

Personal human rights, which include freedom of expression, freedom of religion, freedom of movement and so on

1) Economic rights or property rights, namely the right to own something, buy, and sell and use it

2) Political rights, namely the right to take along as well as in government, the right to vote (elected and elected in general elections), the right to establish political parties and so on

3) The right to get equal treatment in law and government or the rights of legal equality

4) Social and cultural rights or social culture rights, namely the right to choose education, the right to develop culture and so on. Human rights to receive judicial procedures and protection or procedar rights, namely regulations on detention, arrest, search, justice and so on.

\subsection{Theory of Violence}

Johan Galtung is one of the experts who will be mentioned every time he discusses violence, Galtung himself is a peace activist and has been 30 years of torturing and helping various humanitarian events. According to Galtung "In short, violence is any physical, emotional, verbal, institutional, structural or spiritual condition, as well as behaviors, attitudes, policies or conditions that weaken, dominate or destroy ourselves and others".

\section{Method}

The method in this study the author uses descriptive-explanatory method, which describes and explains a phenomenon of the efforts made by the ACWC (ASEAN Commission on the Promotion and Protection of the Rights of Women and Children) in protecting the rights of Rohingya women in Myanmar. The type of data presented is secondary data. The data collection technique used is library research, which is a technique of collecting data by examining a number of literature relating to the problem being examined both from books, scientific journals, documents and articles which are assessed according to the themes raised in this study. The data analysis technique used in analyzing research data is a qualitative analysis technique, namely by analyzing secondary data that is relevant to the effort to address the rights of women and children.

\section{Result and Discussion}

\subsection{Forms of Violence Against Women in Rohingya}

The execution of the Rohingyas had actually taken place since Myanmar was still called Burma and was colonized by the British in 1824. At that time, the British government promised the Rohingyas a separate land which was a Muslim national territory and therefore the Rohingya preferred to support the British government but, Myanmar nationalists prefer to support the Japanese government. This is where the conflict began, in 1942 when the British government came out of Myanmar the Myanmar government provoked Buddhists in Rakhine which then caused massive riots and caused approximately 100,000 Rohingyas were killed and fled to East Bengal. In 1948 when Myanmar succeeded in independence from Britain, a bloody conflict broke out between various segments of ethnic and racial groups totaling more than one hundred .

Burma Citizenship Law 1982, the Myanmar government does not recognize that the 
Rohingya are their citizens, thus making the Rohingya lose their citizenship.

The enactment of the 1982 Burmese Citizenship Law policy also made discrimination against Rohingya ethnicities intensified, many of the Rohingya who fled to Bangladesh and ethnic groups living in Myanmar had to accept human rights violations which were getting worse, especially against women because they were considered as carriers of identity Rohingya ethnicity. Muslim women in Rohingya are not allowed to wear headscarves and rape of Rohingya women is carried out in front of the victim's husband and children, murder and illegal detention are carried out every daY. Noted on August 25, 2017, in addition to mass killings, other atrocities including the burning of dwellings, torture, rape, kidnapping continues to be carried out on ethnic Rohingya living in Myanmar. There are around 603,000 Rohingya refugees who have fled to Bangladesh and 51 percent of them are women and 30,000 of them are women who are already pregnant and do not have access to health or a doctor regarding their womb. According to Save the Children, an international non-government organization from the United States, it is estimated that in 201850,000 babies will be born to Rohingya women in refugee camps in Bangladesh. Their physical and mental health status has entered a serious level and has become a global problem that requires immediate action. The magnitude of violence is much higher among adolescent girls and women of reproductive age. Estimates of the MSF (Medecins Sans Frontieres) reveal that at least $2.6 \%$ of women and girls have died due to sexual violence. In addition, rape survivors reported being traumatized for days with genitals that were swollen and torn during their trip to Bangladesh. Most victims do not have access to urgent drugs such as emergency contraception (within 120 hours) and prophylaxis against HIV infection (within 72 hours) and so on, due to stigma and inability to meet health care costs.

\subsection{ASEAN Commission on the Promotion and Protection of the}

Rights of Women and Children (ACWC) Policy in the Case of Women's Violence in Rohingya.

Based on the awareness of the importance of human rights issues, ASEAN has formed several integral organizations that deal with human rights issues, one of which is, the ASEAN Commission on the Promotion and Protection of the Rights of Women and Children (ACWC) is part of ASEAN which is a regional human rights mechanism of ASEAN which is devoted to children and women. The establishment of the ACWC began with the 10th ASEAN Summit in November 2004, at the ASEAN Summit when ASEAN leaders agreed to adopt the 20042010 Viantine Action Program (VAP). VAP is a work program of ASEAN to realize the ASEAN Vision 2020, VAP stands on the three pillars of ASEAN cooperation namely, politics and security, economic integration and social cultural cooperation to form the ASEAN Security Community, which among others calls for the formation of ACWC in order to realize security in the ASEAN region. VAP is also the forerunner to the establishment of ACWC. Then it continued into 2008 where ASEAN included human rights in the ASEAN charter and formed a special body for human rights with the aim and conformity with the principles relating to the protection of human rights and fundamental freedoms. In 2009, at the 14th ASEAN Summit ASEAN leaders adopted the Cha-am Hua Hin declaration, in this declaration there were plans for the ASEAN Political Security Community (APSC) and a plan for the ASEAN Socio-Cultural Community (ASCC) both plans that reaffirmed the establishment of ACWC. ACWC itself was inaugurated in Hanoi, Vietnam on 7 April 2010 at the 16th ASEAN Summit.According to the Terms of Reference of ACW the objectives of the ACWC are:

1) To promote and protect the basic human rights and freedoms of women and children in ASEAN, taking into account the different historical, political, sociocultural, religious and economic contexts 
in Indonesia and the balance between rights and responsibilities.

2) To uphold, promote, protect, respect and fulfill the rights of women and children in ASEAN to live in peace, equality, justice, dignity and prosperity.

3) To promote the welfare, development, empowerment and participation of women and children in the ASEAN Community the development process which contributes to the realization of the ASEAN goals as set out in the ASEAN Charter.

4) To enhance regional and international cooperation with a view to complementing national and international efforts to promote and protect the rights of women and children.

5) To uphold human rights as determined by the Universal Declaration of Human Rights, the Vienna Declaration and Program for Action, CEDAW, CRC, the Beijing Platform for Action (BPFA), World Fit for Children, International Humanitarian Law and other international human rights instruments and regional declarations related to women and children's rights to ASEAN Member States are parties.

6) To promote stability and harmony within the region, friendship and cooperation among ASEAN Member States.

While the principles of ACWC according to the Terms of Reference of ACWC are:

1) To respect the principles of ASEAN as stated in Article 2 of the ASEAN Charter.

2) To respect the principles of human rights, including universality, inseparability, interdependence and the interrelation of all fundamental freedoms and the rights of women and children, the guiding principles of CEDAW and CRC.

3) To respect the principles of impartiality, objectivity, non-selectivity, nondiscrimination and avoiding double standards and politicization.

4) To complement, not duplicate, the functions of the CEDAW and CRC Committees.
5) Recognizing that primary responsibility for promoting and protecting the fundamental freedoms and rights of women and children lies in each Member State.

6) To pursue constructive nonconfrontational and cooperative approaches to increase the promotion and protection of the rights of women and children.

7) To ensure a balance between promotion and protection of the rights of women and children.

8) To adopt an evolutionary approach that will contribute to the realization of the rights of women and children in ASEAN.

ACWC focuses on promoting and protecting fundamental freedoms of women and children in ASEAN based on the Convention on the Elimination of All Forms of Discrimination against Women (CEDAW) and the Convention on the Rights of the Child (CRC).

1) To promote the implementation of international instruments, ASEAN instruments and other instruments related to the rights of women and children.

2) To develop policies, programs and innovative strategies to promote and protect the rights of women and children to complement the building of the ASEAN Community.

3) To promote public awareness and education about the rights of women and children in ASEAN.

4) To advocate on behalf of women and children, especially the most vulnerable and marginalized, and encourage ASEAN Member States to improve their situation.

5) To build the capacity of relevant stakeholders at all levels, e.g. administrative, legislative, judicial, civil society, community leaders, women's and children's machinery, through the provision of technical assistance, training and workshops, towards the realization of the rights of women and children. 
6) To assist, at the request of ASEAN Member States, in preparing the CEDAW and CRC Periodic Reports, Human Rights Universal Periodic Review Board (UPR) and reports for other Treaty Bodies, with specific reference to the rights of women and children in ASEAN.

7) To assist, at the request of ASEAN Member States, in implementing the Observation Conclusions of CEDAW and CRC and other Treaty Bodies relating to the rights of women and children.

8) To encourage ASEAN Member States to collect and analyze disaggregated data based on sex, age, etc., related to the promotion and protection of the rights of women and children.

9) To promote studies and research relating to the situation and welfare of women and children with a view to fostering effective implementation of the rights of women and children in the region.

10) To encourage ASEAN Member States to conduct periodic national reviews of laws, regulations, policies and practices related to the rights of women and children.

11) To facilitate the sharing of experiences and good practices, including thematic issues, between and among ASEAN Member States regarding the situation and welfare of women and children and to enhance the effective implementation of CEDAW and CRC through, inter alia, exchange of visits, seminars and conference.

12) To propose and promote appropriate actions, mechanisms and strategies for the prevention and elimination of all forms of violations of the rights of women and children, including the protection of victims.

13) To encourage ASEAN Member States to consider accessing, and ratifying, international human rights instruments related to women and children.

14) To support the participation of ASEAN women and children in the dialogue and consultation process in ASEAN related to the promotion and protection of their rights.

15) To provide consultancy services on various matters relating to the promotion and protection of the rights of women and children for ASEAN sectoral bodies upon request.

16) To carry out other tasks related to the rights of women and children as delegated by ASEAN Leaders and the Minister of Foreign Affairs

3.3 Constraints on the Implementation of the ACWC Policy in Dealing with Violence against Women in Rohingya

As an organization ACWC certainly have a workplan to be executed within the time specified, In the workplan ACWC contained thematic areas Elimination of violence against women and children and then explicitly mentioned in goal ACWC listed in the Terms of refrences ACWC in points sixth " To pursue constructive non-confrontational and cooperative approaches to enhance the promotion and protection of the rights of women and children "and the twelfth point in the ACWC's mandate and function which is also stated in the ACWC Terms of Refrences," To propose and promote appropriate actions, mechanisms and strategies for the prevention and elimination of all forms of violations of the rights of women and children, including the protection of victims ." Seeing the violence that occurred against Rohingya women, then why does ACWC as an organization seem helpless in handling the case? The answer is because ASEAN adheres to the principle of non-intervention. This principle appears in the Treaty of Amity and Cooperation in Southeast Asia (TAC), February 24, 1976 which in Article 2 explained that in establishing relations between members, based on fundamental principles namely: (a) respecting freedom, sovereignty, equality, territorial integrity and national identity of each nation; (b) each country has the right to regulate the administration of its country free from external intervention; (c) the principle of nonintervention in internal relations among 
members. This principle is also contained in the ASEAN charter Article 2 Paragraph 2 point (e) which reads "non-interference in the domestic affairs of ASEAN Member States" and (f) "Respect for the right of each Member State to maintain its national existence free from external interference, subversion and force." The existence of these two articles strengthens the existence of the principle of non-intervention in ASEAN. The existence of this principle creates a positive and negative side, the positive side of ASEAN as an integrated security region tends to be safe and stable, but the negative side is the obstruction of conflict resolution assistance that occurs in the ASEAN region.

If we look at it from the perspective of human rights, then the principle of non-intervention is legitimate as long as there is a common view in viewing human rights values, but in the ASEAN region the implementation of this principle only worsens the humanitarian crisis so that individuals and groups who are pressured by the country's government cannot access the main aspects of human security which is proclaimed by the United Nations, namely security for themselves ( personal security), economic security ( economic security), food security ( food security), health security ( health security), the security environment (environmental security ), community security ( community security) and political security (political security). Then, if seen through the constructivism perspective, the principle of non-intervention is present because of ideas that have failed to construct. The constructivist itself has several non-material components that are as important as the material components, namely culture, norms and identity. Constructivists assume that when cooperation between countries does not proceed accordingly it means that in cooperation there is no sense of community among members, the absence of sense of community is due to the idea of shared knowledge that fails to be constructed, this shared knowledge is formed by identity and interests actor. Identity itself is more determined by shared ideas than natural factors . Identity for constructivists is not just one, but there are four types of identity, namely, corporate identity, type, role and collective. Identity is not something that just happens, but there are entities that are socially constructed. In ASEAN itself, collective identity fails to form, collective identity itself can be formed from interdependence, equality of perception, homogeneity and self-restraint principles. See the factors described above to obtain the collective identity of ASEAN should improve factor equation perception and homogeneity because when the collective identity has been established successfully it will create solidarity or community region in which when it is created ak tor-actor International in a region will have the perception and the same interests and then give birth to a joint act

As for the Rohingya case itself, especially seeing violence against women, ASEAN countries have a variety of responses, some have pressured Myanmar to open diplomacy so that problems can be resolved and some consider that what happened in Myanmar is an internal problem that cannot be contested as the principle of non-intervention from ASEAN itself. According to ASEAN representative Joshua Kurlantzick, collective action from each ASEAN country is difficult because this is how ASEAN works. Therefore ASEAN member countries act individually either by sending direct assistance or trying to establish bilateral relations with Myanmar.Because ASEAN still holds the principle of nonintervention, the crisis that has plagued the Rohingya community in Myanmar's Rakhine State continues to increase alarmingly. Neighboring Myanmar countries can not do much as well as ASEAN or ACWC which, in the end ACWC as an organization can only hold meetings to discuss the problem of women in the Rohingya without being able to do the real thing.Along with the development of the global political constellation, it seems that this principle must begin to be abandoned by ASEAN. Because in the ASEAN Charter it is stated that the aim of ASEAN going forward is to "maintain and enhance peace, security and stability and 
further strengthen peace-oriented values in the region, and to enhance regional resilience by promoting greater political, security, economic and socio-cultural cooperation" . This statement shows that ASEAN going forward is a single entity, this is also strengthened by the jargon of ASEAN, One Vision, One Identity, One Community.

\section{Conclusion}

Human rights are rights inherent in humans from birth, where humans are also blessed with a mind and conscience. Human rights are universal which means that this right is declared as part of human beings beyond the boundaries of the country, nationality and is aimed at every person, poor or rich, normal male or female or disabled person. If we look at the implementation of human rights among ASEAN member countries, the implementation of human rights is still far from good words, one of which is a prolonged conflict in the Rohingya that is filled with human rights violations. Victims continue to fall every day including women, women get a lot of physical, psychological and sexual violence. Many Rohingya women claimed to have been raped by the Burmese army to the point of suffering deep injuries and severe trauma.

As an organization devoted to managing women's rights and children, it is fitting for ACWC to intervene in the issue of human rights violations, especially against women in Rohingya but, in reality there is nothing significant that ACWC can do because it is hampered by the principle of non-intervention. The existence of the principle of non-intervention limits the work of the ACWC. According to the theory of constructivism, the principle of non-intervention exists because the failure of the actors constructing the idea of shared knowledge, the failure of constructing this idea causes no sense of community and also causes no commitment to existing institutions.Seeing current political conditions and developments, the principle of nonintervention must be immediately abandoned because this principle impedes ASEAN from advancing and controls the stability of security within the region and also prevents making ASEAN as a single entity such as ASEAN jargon, One Vision, One Identity, One Community .

\section{References \\ Book}

Buzan, Barry, Ole Waever, and Jaap de Wilde. (1998). Security: A New Framework for Analysis. Lynne Colorado: Rienner Publisher.

Clive Archer. (2001). International Organizations; Third Edition. New York : Routledge.

E. Adler. (2005). Communitarian International Relations: The Epistemic Foundations of International Relations. London: Routledge. hlm. 181

E. Adler and M. Barnett. (1998). 'Security communities in theoretical perspectives,' dalam E. Adler and M. Barnett (eds.). Security Communities, Cambridge: Cambridge University Press.

Folker, Jennifer Sterling. (2003). "Constructivist Approaches" dalam Jennifer Sterling Folker. Making Sense of International Relations Theory. London: Lynne Rienner Publisher.

Jackson, Robert dan George Sorensen, terj. Dadan Suryadipura. (2005). Pengantar Studi Hubungan Internasional. Yogyakarta: PustakaPelajar.

Naning, Ramdlon. (1983). Cita dan Citra Hak-Hak Asasi Manusia di Indonesia, 
Journal Sampurasun : Interdisciplinary Studies for Cultural Heritage

Vol. VI, Number 01, June 2020

Lembaga Kriminologi. Indonesia: Universitas Indonesia.

Trianita, (2002). Hendriati dalam Surya diRadjab. Dasar-Dasar Hak Asasi Manusia., Jakarta: PBHI.

W. Matlii. (1999). The Logic of Regional Integration: Europe and Beyond. Cambridge: Cambridge University Press.

\section{Thesis and Journal}

Anugrah, Adi W. 2009.

KonstruktivismedalamPembelajaranHubu nganInternasionaldiaksesdarihttp://awanx hi.wordpress.com/2009/02/08/konstrukti visme-dalam-pembelajaranhubunganinternasional/. Kamis 14.10.2010. 11:29 WIB

Ayu, Tamian Dian. (2012). “Tinjauan Hukum Internasional terhadap Etnis yang Tidak Memiliki Kewarganegaraan: Studi Kasus Etnis Rohingya, Myanmar", FH. UI. Jakarta.

Pramono, Aris. (2010). Peran UNHCR dalam Menangani Pengungsi Myanmar Etnis Rohingya di Bangladesh (periode 19782002. FISIP. UI. Jakarta

Ramadhani, Bayu Azhari. (2014). Peran OHCHR Dalam Mengatasi Kasus HAM yang Terjadi Pada Etnis Rohingya di Myanmar Tahun 2012. Fakultas Ilmu Sosial Ilmu Politik. Universitas Islam Negeri Syarif Hidayatullah. Jakarta.

Soeparna, Intan. (2018). The Protection of Women Refugees based on the Prespective of ASEAN Law: The Case of Rohingya Refugees. https://doi.org/10.22304/pjih.v5n2.a2. 21 September 2018. 8 November 2018.

\section{Website}

Eilish, "Two Months On: Rohingya Refugee Crisis", http://www.oxfam.org.nz/blogs/2017/10/ 26/two-months-rohingya-refugee-crisis, diaksespada\&Februari 2019

Editorial. Our responsibility to protect the Rohingya. Lancet. com. 2017 Dec 23;390(10114):2740. Available from: https://www.

thelancet.com/journals/lancet/article/PIIS 0140-6736(17)33356-

1/fulltext?code=lancet-site

Medecins Sans Frontieres. Myanmar/Bangladesh: MSF surveys estimate that at least 6,700 Rohingya were killed during the attacks in Myanmar. Msf.org. 2017 [cited 2018 Mar 18]. Available from: http://www.msf.org/ en/article/myanmarbangladesh-msfsurveys-estimate-least-6700- rohingyawere-killed-during-attacks

Medecins Sans Frontieres.. "No one was left" Death and violence against the Rohingya in Rakhine state, Myanmar. Msf.org. 2018 Mar[cited 2018 Mar 18]. Available from:

https://www.doctorswithoutborders.ca/sit es/ default/files/2018_-_03__no_one_was_left__advocacy_briefing_on_ mortality_surveys.pdf

Melacak Asal Usul Etnis Rohingya, dalam Republika (Online), Jakarta, 31 Mei 2015, dalam

http://www.republika.co.id/berita/koran/i slam-digest-koran/15/05/31/np7rojmelacak-asal-usul-etnis-rohingya. diakses 21 Oktober 2018.

Human Rights Watch. "All my body was pain”.Sexual violence against Rohingya women and girls in Burma. HRW.org. 2017 Nov 6 [cited 2018 May 2]. Available from: https://www.hrw.org/report/2017/11/16/a ll-mybody-was-pain/sexual-violenceagainst-rohingya-women-and-girlsburma 
Journal Sampurasun : Interdisciplinary Studies for Cultural Heritage

Vol. VI, Number 01, June 2020

Sejarah Presekusi Rohingya, dalam The Conversation, 25 September 2017, dalamhttp://theconversation.com/sejarahpersekusi-rohingya-di-myanmar-84520, diakses 7 Februari 2019. 